\title{
PENGEMBANGAN MEDIA PEMBELAJARAN BERBASIS MULTIMEDIA INTERAKTIF UNTUK GURU IPA DI SEKOLAH MENENGAH PERTAMA
}

\author{
Winna Dharmayanti ${ }^{1 *}$, Dini Oktarika ${ }^{2}$ \\ ${ }^{1,2}$ Pendidikan Teknologi Informasi dan Komputer IKIP PGRI Pontianak, Jalan Ampera No 88 Pontianak \\ Kalimantan Barat Indonesia \\ *email: dharmayantiwinna@gmail.com
}

\section{Received: 21 April 2019 Accepted: 1 Juni 2019 Published: 30 Juni 2019}

\begin{abstract}
Abstrak
Penelitian ini mengembangkan media pembelajaran berbasis multimedia interakif sesuai kebutuhan guru di sekolah menengah pertama dengan materi gejala biotik dan abiotik metode yang digunakan dalam penelitian ini adalah Research and Development $(R \& D)$ dengan rancangan ADDIE. Tahapan pengembangan meliputi analysis, design, development, implementation dan evaluation. Hasil penelitian menunjukkan bahwa kelayakan dari aspek media diperoleh persentase 86,5\% dengan kategori sangat baik. Sedangkan berdasarkan aspek materi mendapatkan persentases sebesar 84,8\% dengan kategori sangat baik. Hal tersebut menandakan bahwa media yang dikembangkan bisa digunakan. Dari hasil Uji terbatas mendapatkan presentase kelayakan sebesar $81,7 \%$ yang termasuk kategori sangat baik, dan dari hasil respon guru yang menggunakan media dengan presentase $68 \%$ dengan kategori baik.
\end{abstract}

Kata kunci: media pembelajaran, multimedia interaktif, ilmu pengetahuan alam

\begin{abstract}
This study develops interactive multimedia-based learning media according to the needs of teachers in junior high schools with biotic and abiotic symptom material the method used in this study is Research and Development $(R \& D)$ with the ADDIE design. The stages of development include analysis, design, development, implementation, and evaluation. The results showed that the feasibility of the media aspect obtained a percentage of $86.5 \%$ with a very good category. While based on the material aspects get percentages of $84.8 \%$ with very good categories. This indicates that the media developed can be used. From the results of the limited test, the feasibility percentage was $81.7 \%$, which included a very good category, and from the results of the teacher's response using the media with a percentage of $68 \%$ in the good category.
\end{abstract}

Keywords: learning media, interactive multimedia, natural science

(C) 2019 LPPM IKIP PGRI Pontianak, Indonesia

\section{PENDAHULUAN}

Mengajar merupakan suatu proses penyampaian informasi atau pengetahuan dari guru kepada siswa. Mengajar merupakan suatu proses yang interaktif, yang melibatkan interaksi antara siswa, guru dan lingkungan sekitar. Guru harus mampu menciptakan kondisi kelas yang kondusif dalam proses pembelajaran agar proses pembelajaran dapat berjalan dengan optimal 
dan dapat menarik minat dan motivasi belajar siswa. Dengan demikian penggunaan media pengajaran juga perlu diperhatikan demi tercapainya tujuan pembelajaran.

Seorang guru diharapkan mampu untuk menciptakan media pembelajaran sesuai dengan bidang ilmu yang di ajarkan, ini akan membantu guru tersebut dalam penyampaian informasi yang optimal, salah satunya media pembelajaran berbasis komputer. Menurut (Zamani, 2016) pemanfaatan teknologi komputer untuk membuat media pembelajaran mempunyai banyak keunggulan, salah satunya yaitu pembelajaran lebih inovatif dan interaktif, karena dapat menggabungkan antara teks, audio, gambar, animasi, dan video menjadi satu kesatuan yang saling melengkapi yang dapat dikenal sebagai media pembelajaran berbasis multimedia interaktif. saat ini Pengunaan media komputer dalam pembelajaran merupakan hal yang sangat diminati bagi guru dan siswa di sekolah selain mengurangi verbalitas di kelas media komputer juga mampu menciptakan tampilan yang menarik.Media Komputer Juga merupakan media terkini yang sedang gencar dikembangkan diberbagai bidang pendidikan.Terintegrasi antara teks, video, animasi bergerak hingga audio visual yang beragam jenis dan bentuknya inilah yang menjadi pertimbangan guru dalam pengunaan media komputer dalam proses pembelajarannya, diharapkan mampu menciptakan suasana yang menyenangkan dan lebih diserap oleh siswa dengan tampilan yang lebih menarik.

Namun pada kenyataannya masih banyak guru yang kurang memahami dan kreatif dalam pembuatan media, hingga kurangnya memanfaatkan media komputer dalam pembelajaran, guru masih melakukan proses pembelajaran dengan media buku dan papan tulis saja. Hal ini dilatar belakangi dari berbagai aspek, usia guru yang tidak lagi muda, jenis kelamin , serta kurang berminatnya guru itu sendiri dengan media komputer hingga keterbatasan dalam penguasaan teknologi khususnya komputer. Berdasarkan hasil pengamatan di di Sekolah Menengah Pertama Pontianak terungkap beberapa permasalahan yang terjadi yakni proses pembelajaran masih bersifat konvensional di dalam kelas, masih belum memanfaatkan penggunaan teknologi khususnya media komputer di didalam kelas, sedangkan fasilitas yang dimiliki telah memadai mempunyai laboratorium komputer. Selain itu proses pembelajaran pepusat kepada guru.

Berdasarkan hasil pengamatan tersebut dilakukanya studi pendahuluan yang diperoleh informasi bahwa keinginan guru IPA di Sekolah Menengah Pertama MGMP di Kabupaten Bengkayang dengan materi gejala biotik dan abiotik yakni dibutuhkannya media komputer yang dapat menunjang pembelajaran di dalam kelas misalnya menggunakan multimedia interaktif. 
Dari kebutuhan tersebut maka peneliti menawarkan sebuah pengembangan media yaitu multimedia interaktif yang lebih menarik.

Penggunaan media pengajaran sangat diperlukan dalam kaitannya dengan peningkatan mutu pendidikan. Tujuan penggunaan media pengajaran adalah (Akhmad, 2008): a) Agar proses belajar mengajar yang sedang berlangsung dapat berjalan dengan tepat guna dan berdaya guna. b) Untuk mempermudah bagi guru/pendidik daiam menyampaikan informasi materi kepada anak didik. c) Untuk mempermudah bagi anak didik dalam menyerap atau menerima serta memahami materi yang telah disampaikan oleh guru/pendidik. d) Untuk dapat mendorong keinginan anak didik untuk mengetahui lebih banyak dan mendalam tentang materi atau pesan yang disampaikan oleh guru/pendidik. e) Untuk menghindarkan salah pengertian atau salah paham antara anak didik yang satu dengan yang lain terhadap materi atau pesan yang disampaikan oleh guru/pendidik.

Menurut Diartono (2008) bahwa multimedia adalah kombinasi dari penggunaan beberapa media seperti film, slide, musik, penerangan dengan text, image, khususnya untuk tujuan pendidikan, dan hiburan. Unsur-unsur seperti teks, audio (narasi, dialog, sound effect), musik, film, video, fotografi, animasi dan grafik merupakan media pendukung yang tergantung dan terintegrasi menjadi satukesatuan karya multimedia. Bentuk Interaktif Multimedia termasuk didalamnya WebSite, CD Rom Interactive, Program/software, Presentasi, Tutorial, Help section, dan bahkan Games.

Dalam pembelajaran, peranan multimedia berbasis komputer menjadi semakin penting di masa kini, karena sistem multimedia yang terdiri dari komponen media-media (teks, gambar, grafis, animasi, audio dan video) tersebut dirancang untuk saling melengkapi sehingga menjadi suatu sistem yang berdaya guna dan tepat guna, di mana suatu kesatuan menjadi lebih baik daripada jumlah bagian-bagiannya. Penggunaan multimedia berbasis komputer ${ }^{2}$ dapat diterima dalam pembelajaran atas dasar mempertinggi proses belajar mandiri serta peran aktif dari siswa (CBSA). Sistem multimedia berbasis komputer juga memberikan rangsangan bagi proses pembelajaran yang berlangsung di luar ruang kelas 7. Selanjutnya, peran multimedia berbasis komputer dalam pembelajaran adalah dapat memberikan jawaban atas suatu bentuk pembelajaran yang dulunya secara tradisional belum dapat dilaksanakan. Berdasarkan latar belakang yang telah diuraikan maka tujuan dari penelitian ini adalah mengembangkan media pembelajaran berbasis multimedia interaktif untuk guru IPA di Sekolah Menengah Pertama. 


\section{METODE}

Penelitian menggunakan jenis penelitian kualitatif deskriptif. Penelitian ini merupakan penelitian research and development $(R \& D)$. Adapun tahapan pengembangan meliputi Analysis, Design, Development, Implementation dan Evaluation Konsep dari ADDIE menurut (Branch, 2009).

\section{Tahap Analisis (Analysis)}

\section{Analisis Kinerja}

Analisis kinerja dilakukan untuk mengembangkan sebuah produk berupa media pembelajaran, digunakan untuk memudahkan guru MGMP IPA dikabupaten bengkayang dalam proses pembelajaran di kelas . Berdasarkan observasi yang dilakukan di pada MGMP IPA dibengkayang . Pada saat pembelajaran di kelas siswa sebagian besar kurang memperhatikan guru pada saat menyampaikan materi pelajaran di kelas. Siswa mengalami kebosanan dalam pembelajaran sehingga tidak fokus terhadap apa yang disampaikan oleh guru.

Masalah juga dihadapi oleh guru pada saat pembelajaran di kelas, diantaranya adalah guru menyampaikan materi dengan metode ceramah tanpa divariasikan dengan penggunaan media pembelajaran. Guru mengalami kesulitan pada saat menyampaikan materi-materi yang membutuhkan visualisasi dalam penyampaiannya. Guru membutuhkan waktu yang cukup banyak dalam penyampaian materi, sehingga siswa tidak sepenuhnya aktif dalam pembelajaran.

\section{Analisis kebutuhan Guru}

Analisis kebutuhan yang meliputi kebutuhan dan karakteristik guru yang akan menjadi sasaran pengguna media pembelajaran Ilmu Pengetahuan Alam. Penelitian ini berdasarkan hasil dari observasi pada MGMP IPA di Kabupaten bengakayang. Berdasarkan observasi yang telah dilakukan, sebagian besar guru kurang bisa memanfaatkan teknologi yang sedang berkembang , dalam proses pembelajaran guru cendrung masih menggunkan metode ceramah sehingga proses pembelajaran kurang efektif karena siswa kurang termotivasi untuk memperhatikan pada saat guru menyampaikan materi pembelajaran. Menjadikan teknologi yang dimiliki dan diminati oleh siswa sebagai salah satu sumber belajar yang menarik. Media pembelajaran dengan teknologi yang menggabungkan teks, gambar, video dan animasi yang dikemas menjadi sumber belajar pendukung yang dapat memotivasi siswa untuk belajar. 


\section{Analisis Kompetensi}

Analisis kompetensi dan intruksional yang meliputi analisis terhadap Kompetensi Inti (KI) yang akan dimuat dalam media pembelajaran ini. Kompetensi Inti yang dijadikan sebagai materi utama yang dimuat pada media pembelajaran ini yakni Kompetensi Inti hanya satu sub bahasan pada mata pelajaran Ilmu Pengetahuan Alam, yakni Gejala Biotik dan Abiotik

\section{Analisis Sarana dan Prasarana}

Analisis sarana sekolah yaitu tersedianya fasilitas teknologi informasi dan komputer di sekolah. Sarana komputer yang ada belum sepenuhnya dimanfaatkan sebagai media penyampaian materi pembelajaran di kelas. Tersedianya sarana teknologi de sekolah dapat dijadikan sebagai media pembelajaran yang mendukung metode konvensional dalam penyampaian materi pelajaran.

Sekolah menyediakan ruangan laboratorium komputer dengan peralatan teknologi berupa Personal Computer (PC), proyektor LCD dan speaker aktif yang dapat dimanfaatkan oleh guru sebagai media pembelajaran. Menggunakan teknologi informasi dan komputer sebagai media pembelajaran yang dapat memudahkan guru dalam menyajikan materi pembelajaran dan pembelajaran menjadi lebih menarik perhatian siswa. Memanfaatkan sarana teknologi informasi dan komputer sebagai media pembelajaran dikelas.

\section{Analisis Kebutuhan Media}

Pembuatan media pembelajaran IPA ini memerlukan hardware dan software yang sesuai. Software yang digunakan untuk pembuatan media pembelajaran yaitu Adobe Flash Profesional CS 6 dan Adobe Premiere CS 6. Hardware yang dibutuhkan untuk membuat media pembelajaran ini adalah Prosessor Intel Core, VGA 1 GB, RAM 4 GB, Hardisk 8 GB dan Monitor 800 x 600 pixel

\section{Tahap Desain Produk}

\section{Persiapan Materi}

Sebelum pembuatan desain produk media pembelajaran terlebih dahulu mempersiapkan materi yang akan dimuat pada media pembelajaran. materi ini dijadikan dasar dalam mengembangkan desain media pembelajaran Ilmu Pengatahuan Alam. Penyusunan materi berdasarkan silabus mata pelajaran Dasar. Selain penyusunan materi ditahap ini juga Pada tahap ini juga dilakukan penyusunan soal. 


\section{Pembuatan Desain Produk}

Pada tahap pembuatan desain media dihasilkan flowchart dan storyboard. Selanjutnya perancangan flowchart yang bertujuan untuk memanajemen tiap halaman yang akan dibuat serta untuk mempermudah dalam proses pembuatan media sehingga proses perancangan media dapat terstruktur dan terencana dengan baik. Pada tahap ini juga dihasilkan storyboard. Perancangan storyboard untuk mendesain antarmuka media sehingga dapat memberikan gambaran mengenai pembuatan media pembelajaran Ilmu Pengetahuan Alam.

\section{Tahap Pengembangan (Development)}

Tahap pengembangan merupakan proses pengembangan materi-materi yang telah disusun berupa teks, gambar. Kombinasi atau penggabungan materi-materi berupa teks, gambar, dilakukan dengan menggunakan berbagai software yaitu Adobe Flash Profesional CS 6.

Pada tahap ini produk media pembelajaran dibuat sesuai dengan format yang sudah ditentukan sehingga menghasilkan file produk media pembelajaran. Secara garis besar menu yang tercantum pada media pembelajaran gejala Biotik an abiotik. Secara garis besar menu halaman yang termuat pada media pembelajaran adalah menu profil, glosarium, menu KI-KD, menu konten materi dan menu latihan soal. Menu profil berisi tentang identitas profil pengembang media pembelajaran sepert identitas dosen pembuat. Menu glosarium berisi kamus dalam bentuk yang ringkas daftar kata- kata dan penjelasannya dalam bidang tertentu. Menu KIKD berisi Kompetensi Inti mata pelajaran Ilmu Pengetahuan Alam. Menu konten materi berisi materi tentang pengamatan tentang gejala biotik dan Abiotik. sub materi dengan penyajian berupa teks dan gambar. Menu latihan soal berisi soal-soal mengenai materi . Menu quiz berisi kumpulan soal dalam bentuk pilihan ganda sebanyak 5 nomor. Setelah menjawab soal maka akan menampilkan jumlah jawaban yang benar dan skor akhir yang diperoleh.

\section{Tahap Implementation (Implementasi)}

Pada tahap implementasi media pembelajaran Ilmu Pegetahuan Alam diujicoba kepada kelompok kecil atau terbatas yang terdiri dari 5 orang guru kemudian diminta untuk menilai produk guna untuk perbaikan media tersebut. Setelah itu dilakukanya perbaikan dan revisi produk. Selanjutnya uji coba lapangan kepada 30 guru untuk mengetahui respon guru setelah diimpilmentasikan media tersebut. Implementasi media digunakan sebagai penunjang sumber belajar untuk siswa. 
Adapun langkah-langkah implementasi media pembelajaran Ilmu Pengetahuan Alam.dilakukan kepada guru adalah persiapan media, implementasi media pada guru secara terbatas dan uji lapangan untuk mengetahui respon serta pemberian angket kepada guru untuk mengetahui respon setelah menggunakan media.

\section{Tahap Evaluation (Evaluasi)}

Pada tahap evaluasi dilakukanya evaluasi media pembelajaran gejala biotik dan berbasis multimedia interaktif berdasarkan hasil dari ahli media dan ahli materi. Sedangkan evaluasi formaif dilakukan ketika hasil implementasi produk kepada guru melalui angket respon setelah menggunakan media.

Subjek uji coba produk yang dilaksanakan dalam penelitian ini adalah Guru MGMP IPA dikabupaten Bengkayang sebagai berikut: Subjek coba produk secara terbatas berjumlah 5 orang guru, Subjek coba produk keseluruhan mengambil 30 orang guru.

\section{HASIL DAN PEMBAHASAN}

Validasi media dilakukan oleh ahli media internal yaitu dosen pengajar di IKIP PGRI Pontianak. Ahli materi dari 2 orang guru pengampu mata pelajaran Ilmu Pengetahuan Alam. Aspek media yang dinilai meliputi aspek software aplikasi, navigasi dan aspek tampilan. Uraian hasil penilaian ahli media disajikan pada Tabel 1.

Tabel 1. Skor penilaian dan persentase ahli media (tahap pengembangan)

\begin{tabular}{|c|c|c|c|c|c|}
\hline \multirow[b]{2}{*}{ Penilaian } & \multicolumn{2}{|c|}{ Ahli Media 1} & \multicolumn{2}{|c|}{ Ahli Media 2} & \multirow{2}{*}{$\begin{array}{c}\text { Total Rerata } \\
\text { Skor } \\
\text { perolehan } \\
\text { Ahli Madia }\end{array}$} \\
\hline & $\begin{array}{c}\text { Skor } \\
\text { yang } \\
\text { diperoleh }\end{array}$ & $\begin{array}{c}\text { Rerata } \\
\text { skor }\end{array}$ & $\begin{array}{c}\text { Skor } \\
\text { yang } \\
\text { diperoleh }\end{array}$ & $\begin{array}{c}\text { Rerata } \\
\text { skor }\end{array}$ & \\
\hline Aspek Media & 89 & 3,56 & 84 & 3,37 & 3,47 \\
\hline Persentase & \multicolumn{2}{|c|}{$89 \%$} & \multicolumn{2}{|c|}{$84 \%$} & $86,5 \%$ \\
\hline Kategori Skor & \multicolumn{2}{|c|}{ Sangat Baik } & \multicolumn{2}{|c|}{ Sangat Baik } & Sangat Baik \\
\hline
\end{tabular}

Berdasarkan Tabel 1 diperoleh hasil validai media terhadap produk media pembelajaran Ilmu Pengetahuan Alam dengan nilai ahli media ke 1 skor sebesar 89, rata-rata sebesar 3,56 dan persentase sebesar 89\% dengan kategori sangat baik. Sedangkan hasil nilai ahli media ke 2 skor sebesar 84, rata-rata sebesar 3,37 dan persentase sebesar 84\% dengan kategori sangat baik. Disimpulkan bahwa berdasarkan hasil validasi yang dilakukan oleh ahli media 
dinyatakan layak digunakan dengan rata-rata 3,47 dan persentase 86,5\% dengan kategori sangat baik

Adapun data hasil validasi ahli materi yang dilkaukan oleh dua orang guru Ilmu Pengetahuan Alam terhadap media pembelajaran pengamatan gejala Biotik dan Abiotik pengenalan hardware jaringan komputer berbasis augmented reality dengan 23 pertanyaan dapat dilihat media pada Tabel 2.

Tabel 2. Skor penilaian dan persentase ahli materi (tahap pengembangan)

\begin{tabular}{|c|c|c|c|c|c|}
\hline \multirow{2}{*}{ Penilaian } & \multicolumn{2}{|c|}{ Ahli Materi 1} & \multicolumn{2}{|c|}{ Ahli Materi 2} & \multirow[t]{2}{*}{$\begin{array}{l}\text { Total Rerata Skor perolehan } \\
\text { Ahli Media }\end{array}$} \\
\hline & $\begin{array}{l}\text { Skor yang } \\
\text { diperoleh }\end{array}$ & $\begin{array}{l}\text { Rerata } \\
\text { skor }\end{array}$ & $\begin{array}{l}\text { Skor yang } \\
\text { diperoleh }\end{array}$ & $\begin{array}{c}\text { Rerata } \\
\text { skor }\end{array}$ & \\
\hline Aspek Materi & 78 & 3,39 & 79 & 3,43 & 3,41 \\
\hline Persentase & \multicolumn{2}{|c|}{$84 \%$} & \multicolumn{2}{|c|}{$85 \%$} & $84,8 \%$ \\
\hline Kategori Skor & \multicolumn{2}{|c|}{ Sangat Baik } & \multicolumn{2}{|c|}{ Sangat Baik } & Sangat Baik \\
\hline
\end{tabular}

Berdasarkan Tabel 2 diperoleh hasil validai materi terhadap produk media pembelajaran Ilmu Pengetahuan Alam dengan nilai ahli materi ke 1 skor sebesar 78, rata-rata sebesar 3,39 dan persentase sebesar $84 \%$ dengan kategori sangat baik. Sedangkan hasil nilai ahli materi ke 2 skor sebesar 79, rata-rata sebesar 3,43 dan persentase sebesar 85\% dengan kategori sangat baik. Disimpulkan bahwa berdasarkan hasil validasi yang dilakukan oleh ahli materi dinyatakan layak digunakan dengan rata-rata 3,41 dan persentase 84,8\% dengan kategori sangat baik.

Hasil uji coba secara terbatas oleh perwakilan guru berjumlah 5 orang, dengan jumlah pertanyaan angket 14 , adapun hasil uji coba produk secara terbatas disajikan pada Tabel 3.

Tabel 3. Skor penelitan dan persentase uji coba terbatas (tahap implementasi)

\begin{tabular}{|c|c|c|c|}
\hline No. & Skor & Rerata Skor & Kategori \\
\hline 1 & 55 & 3,92 & Sangat Baik \\
\hline 2 & 57 & 4,07 & Sangat Baik \\
\hline 3 & 56 & 4,0 & Sangat Baik \\
\hline 4 & 59 & 4,21 & Sangat Baik \\
\hline 5 & 59 & 4,21 & Sangat Baik \\
\hline \multicolumn{3}{|c|}{ Total skor } & 286 \\
\hline \multicolumn{3}{|c|}{ Persentase } & $81,7 \%$ \\
\hline \multicolumn{3}{|c|}{ Rerata skor akhir } & 4,08 \\
\hline \multicolumn{3}{|c|}{ Kategori Skor } & Sangat Baik \\
\hline
\end{tabular}


Hasil ujicoba terhadap produk media pembelajaran pengamatan gejala biotik dan abiotik dengan total skor rata-rata 286, rata-rata 4,08 dan persentase $81,7 \%$ dengan kategori sangat baik.

Selanjutnya pada tahap implementasi, setelah responden mengguna media pembelajaran pengamatan gejala biotik dan abiotik biotik kemudian memberikan penilainya melalui angket. Hasil respon guru terhadap produk disajikan pada Tabel 4.

Tabel 4. Hasil respon guru terhadap produk

\begin{tabular}{|c|c|c|c|c|c|c|c|}
\hline No. & Skor & $\begin{array}{l}\text { Rerata } \\
\text { Skor }\end{array}$ & Kategori & No. & Skor & $\begin{array}{c}\text { Rerata } \\
\text { Skor }\end{array}$ & Kategori \\
\hline 1 & 56 & 4 & Sangat Baik & 16 & 44 & 3.14 & Baik \\
\hline 2 & 55 & 3.92 & Sangat Baik & 17 & 48 & 3.42 & Sangat Baik \\
\hline 3 & 56 & 4 & Sangat Baik & 18 & 48 & 3.42 & Sangat Baik \\
\hline 4 & 55 & 3.92 & Sangat Baik & 19 & 42 & 3 & Baik \\
\hline 5 & 49 & 3.5 & Sangat Baik & 20 & 49 & 3.5 & Sangat Baik \\
\hline 6 & 51 & 3.64 & Sangat Baik & 21 & 50 & 3.57 & Sangat Baik \\
\hline 7 & 49 & 3.5 & Sangat Baik & 22 & 43 & 3.07 & Baik \\
\hline 8 & 46 & 3.28 & Baik & 23 & 41 & 2.92 & Baik \\
\hline 9 & 44 & 3.14 & Baik & 24 & 48 & 3.42 & Sangat Baik \\
\hline 10 & 47 & 3.35 & Baik & 25 & 47 & 3.35 & Baik \\
\hline 11 & 50 & 3.55 & Sangat Baik & 26 & 42 & 5.35 & Baik \\
\hline 12 & 47 & 3.35 & Baik & 27 & 44 & 3.14 & Baik \\
\hline 13 & 49 & 3.42 & Sangat Baik & 28 & 46 & 3.28 & Baik \\
\hline 14 & 48 & 3.42 & Sangat Baik & 29 & 46 & 3.28 & Baik \\
\hline 15 & 43 & 3.07 & Baik & 30 & 45 & 3.21 & Baik \\
\hline \multicolumn{3}{|c|}{ Total skor } & \multicolumn{5}{|c|}{1428} \\
\hline \multicolumn{3}{|c|}{ Persentase } & \multicolumn{5}{|c|}{$68 \%$} \\
\hline \multicolumn{3}{|c|}{ Rerata skor akhir } & \multicolumn{5}{|c|}{3,40} \\
\hline \multicolumn{3}{|c|}{ Kategori Skor } & \multicolumn{5}{|c|}{ Baik } \\
\hline
\end{tabular}

Berdasarkan Tabel 4, diperoleh hasil respon guru terhadap produk media pembelajaran pengamatan biotik dan abiotik dengan total skor rata-rata 1428, rata-rata 3,40 dan persentase $68 \%$ dengan kategori baik.

Pada pengembangan media ini menggunakan langkah-langkah pengembangan model ADDIE melalui tahapan Analysis (analisis), Design (desain), Development (pengembangan), Implementation (implementasi) dan Evaluation (evaluasi). Pada tahap pertama pengambangan produk beradasarkan analisis kebutuhan Guru, kebutuhan media terkait tampilan, materi bentuk produk menyesuiakan kebutuhan dan lain-lain. Kemudian di dirancang pada tahap desain, dimana dilakukanya persiapan pengumpulan materi pengamatan biotic dan Abiotik. Selanjutnya 
pada tahap pengembangan dilakukannya pembuatan media dilanjutkan dengan validasi ahli media dan ahli materi. Masih pada tahap pengembangan dimana media yang dibuat dilakukan revisi sesuai hasil validasi para ahli, dan rekomendasi saran memperbaiki media. Sedangkan untuk perbaikan medianya berdasarkan ahli media mencakup penyusuian besar huruf pada text dan warna yang digunakan. Sedangkan berdasarkan saran dari ahli perlu ditambahkan petunjuk penggunaan media. Berdasarkan perbaikan tersebut maka peneliti memperbaiki.

Pada tahap implementasi dilakukanya ujicoba produk secara terbatas kepada 5 guru untuk menguji media. Saran-saran yang diberikan tentang media yakni hanya perbaikan ukuran huruf teks,. Berikutnya dilakukan respon guru setelah diimplementasikan media pembelajaran pengamatan biotik dan abiotik, sehingga memperoleh respon guru sangat menarik dan menyenangkan.

\section{SIMPULAN}

Produk yang dikembangkan dalam penelitian ini adalah pengembangan media pembelajaran ilmu pengetahuan alam dengan materi pengembangan pengamatan biotik dan abiotik, dalam tahapan pengembanganya dilakukan analisis kebutuhan guru dan media, kemudian dilakukan perancangan desain, selanjutnya dilakukan pengembangan produk dengan membuat media. Untuk hasil evaluasi produk diperoleh hasil kelayakan media tersebut pada ahli media yakni menyatakan media yang dikembangkan layak digunakan dengan rata-rata 3,47dan persentase $86,5 \%$ dengan kategori sangat baik. Sedangkan hasil validasi yang dilakukan oleh ahli materi memperoleh rata-rata 3,41 dan persentase 84,8\% dengan kategori sangat baik. Hasil uji coba terbatas adapun hasil yang diperoleh adalah dengan total skor rata-rata 286, rata-rata 4,08 dan persentase $81,7 \%$ dengan kategori sangat baik. Kemudian hasil respon mahasiswa memperoleh dengan total skor rata-rata 1428, rata-rata 3,40 dan persentase $68 \%$ dengan kategori baik.

\section{DAFTAR PUSTAKA}

Branch, R. M. (2009). Instructional design- the ADDIE approach. New York: Springer.

Diartono, D. A. (2008). Media pembelajaran desain grafis menggunakan photoshop berbasis multimedia. Semarang: Unisbank. 
Sudrajat, A. (2008). Pengertian pendekatan, strategi, metode, teknik dan. model pembelajaran. Bandung: Sinar Baru Algensindo.

Zamani, A. Z \& Heru, N. (2016). Pengembangan media pembelajaran berbantuan komputer untuk meningkatkan motivasi dan hasil belajar. Jurnal Pendidikan Matematika dan Sains 4(1), 89100. 